\title{
Article \\ On the Extraction of Rare Earth Elements from Geothermal Brines
}

\author{
York R. Smith 1,* (D), Pankaj Kumar ${ }^{1}$ (D) and John D. McLennan 2,3 \\ 1 Metallurgical Engineering Department, University of Utah, Salt Lake City, UT 84115, USA; \\ pankaj.kumar@utah.edu \\ 2 Energy \& Geoscience Institute, University of Utah, Salt Lake City, UT 84108, USA; jmclennan@egi.utah.edu \\ 3 Chemical Engineering Department, University of Utah, Salt Lake City, UT 84112, USA \\ * Correspondence: york.smith@utah.edu; Tel.: +1-801-581-5775
}

Received: 22 July 2017; Accepted: 15 August 2017; Published: 18 August 2017

\begin{abstract}
The availability of rare earth elements from primary resources has come into question in the last two decades. This has sparked various government and industry initiatives to examine potential rare earth element resources apart from virgin ore bodies. Geothermal fluids are potentially significant sources of valuable minerals and metals, while co-recovery with geothermal energy production would be an attractive sustainable system. In this work, we give a brief survey of data collected on rare earth element concentrations in geothermal fluids. A survey of methods and technologies for extracting rare earth elements from geothermal is discussed along with the feasibility of recovering rare earth elements from geothermal brines. Based on the findings of this study, rare earth element extraction from geothermal fluids is technically possible, but neither economically viable nor strategically significant at this time.
\end{abstract}

Keywords: rare earths; geothermal; brine; extraction

\section{Introduction}

Rare earth elements or metals (REE or REM) play a vital role in many current and emerging technologies. Many renewable energy conversion and storage technologies require the use of REE. Alternatives to REE are not likely in the near future, but still remains an area not well investigated. For the time being, the development of widespread sustainable energy systems will depend on the availability and resources of REE and their minerals.

The abundance of most REE in the earth's crust is actually significantly higher than other commonly exploited elements, including platinum group elements and mercury [1]. The supply of any individual REE depends on the geology of its deposit, the costs of the extraction technology employed, and the price of the REEs extracted. However, REE minerals are rarely found in commercially acceptable concentrations [1]. The scarcity of mineral deposits is aggravated by the fact that REEs are never found alone or in equal or predictable distributions. Differential demand for each REE and crustal abundance variations introduce significant challenges to ensuring a stable domestic mineral supply of these elements [2]. As a further obstacle, rare earth milling and processing is a complex, ore-specific operation that has a potential for environmental contamination when not controlled and managed appropriately [2].

Besides mineral ore bodies, REE are often found in geological fluids [3]. Water and steam warmed by the earth's heat are commercially used to generate electricity [4]. This heat is generated within the earth's core and flows outward into cooler rocks, towards the earth's surface. The hot rock heats recirculating meteoric water. Sometimes, this heated water re-emerges as hot springs. Water reaching the surface is not a requirement for a successful geothermal operation. More commonly, heat is conducted or convected from depths where the meteoric water has been heated. This heated water/steam can 
be recovered from moderately shallow (thousands of feet) wells. At the surface, the thermal energy is converted to electric energy if the temperature is high enough; heating and other direct uses are feasible for lower temperature water [5].

Thermal reservoirs that provide water that is hot enough to be used to generate electricity are commonly found at plate boundaries where faults and volcanoes are common, such as the "Ring of Fire" that borders the Pacific Ocean, where oceanic crust of the Pacific plate collides with continental crust. Other areas where volcanic activity is common occur where continental crust is being broken or pulled apart, such as the African Rift Valley or the Basin and Range of the western US. Volcanoes also occur at "hot spots" in places like Yellowstone National Park and Hawaii. These big volcanoes occur despite the fact they are not associated with plate boundaries. Typically, these hot geothermal reservoirs are exploited at depths of 1 to 2 miles below the surface. Larderello, in Italy, was the first geothermal field in the world to be developed. It has been producing electricity commercially since 1913. Other geothermal fields in the United States, New Zealand, and Mexico have been producing electricity for more than 50 years. District heating in Boise, Idaho has operated since 1892 and in Iceland since the 1930 .

There are three main types of geothermal power plants:

- Dry steam plants use steam from geothermal wells to directly spin a turbine, which drives a generator that produces electricity. The Geysers in northern California, the world's largest single source of geothermal power, uses steam technology.

- Flash plants bring hot water to the surface where it boils to produce steam. The hot water (above about $440{ }^{\circ} \mathrm{F}$ ) "flashes" to steam when pressure is reduced in the surface facility. The steam is then sent directly to a turbine to drive the generator. The remaining liquid water is reinjected.

- Binary cycle plants use hot water to boil an organic fluid similar to the fluid used in air conditioners (a working fluid). The water is never directly in contact with the working fluid-heat is exchanged however. The expanding gas produced by boiling this working fluid is used to spin the turbine and drive the generator. All of the water used in the binary plant is injected into the subsurface, where it is naturally reheated and eventually used again.

After heat extraction at the surface, condensed fluids or cooled liquids are typically reinjected into the subsurface reservoir. REEs can exist in the produced geothermal brines. Their speciation depends on temperature, $\mathrm{pH}$, and salinity [6]. Various premium geothermal environments have been evaluated for the occurrence of REE [7-9]. Geothermal fluids interact with the host rocks and consequently become increasingly saturated with various minerals in accordance with the rock composition, fluid chemistry, temperature, pressure and available ligands. Gallup provides a good overview of mineral laden hydrothermal systems (for example, the Salton Sea in California, and oilfield brines associated with salt domes in the United States' Gulf Coast [10]).

Although the concentrations of REE found in geological fluids is far below that of ore grades, extraction of REE from geological fluids presents a potential method to selectively recover REE while avoiding many potential environmental hazards associated with conventional extraction processes, separation and purification (i.e., mining and milling). Due to the mineralogy of REE ores, individual separation of REEs is currently a difficult and costly process. A facile process requiring less reagents and energy with high individual REE selectivity is of high technological interest to REE metallurgy sector. Moreover, extraction of critical commodity materials using inexpensive methods may help to improve the economic viability of geothermal energy plants. The geothermal industry has a unique opportunity to leverage known and unknown extractable materials with attractive revenue streams and reduction in power generation costs. Geothermal power production has started to be successfully integrated with some extraction of marketable byproducts such as silica, lithium, manganese, zinc and sulfur [8].

The process to recover aqueous REE, although much more facile compared to mining, still presents its own technical and environmental challenges. The objective of this work is to give a brief survey of 
REE resources in geothermal fluids and discuss potential methods to recover REE from geothermal fluids and technical viability.

\subsection{Background}

Rare earth elements (REE), as defined by the International Union of Pure and Applied Chemistry (IUPAC), consist of the 15 lanthanide elements (La to Lu), as well as scandium (Sc) and yttrium (Y). Although well known within the scientific community and applied in technologies for some time, REE were rather unknown to the general public till about the late 2000s. Around this time, global availability of REEs appeared to be at substantial risk for a number of reasons. In 2009, 80-90\% of the world's production of REE was from China [11] (which still remains today). With essentially a monopoly on the production of these elements, China changed its position towards the worldwide rare earth market. Introduction of production quotas, export quotas and export taxes, enforced environmental legislation, and granting no new rare earth mining licenses [12,13] caused global market volatility and anxiety among manufacturers of high-tech products containing REE. As a result, there has been increased interest and investigation into non-Chinese REE resources, extraction, separation and purification.

\subsection{Technological Importance}

The commercial significance of REEs is not directly reflected in the volume in which they are used or produced. For example, their annual primary production tonnage is approximately two orders of magnitude less than copper and four orders of magnitude less than iron [14]. However, in 2010, the U.S. Department of Energy released a Critical Materials Strategy report outlining the vital role that REE (and other materials) play in a clean energy economy [15]. This group of elements also plays a vital role in other current technologies such as catalysts, magnets and display technologies.

The U.S. Department of Defense is a large consumer of REE. The military uses REE in precision guidance weaponry, communications, night vision goggles, GPS equipment, batteries, and magnets as well as for metal alloys for armored vehicles and projectiles. In addition, REE are used extensively for communications, photovoltaics, thin-films, medical imaging, and other commercial applications.

The United States led global production of REEs from the 1960s to the 1980s. Since then, processing and manufacturing of the world's supply of REEs - as well as downstream value-added products such as metals, alloys and magnets-have shifted almost entirely to China [16]. In recent years, there is a renewed focus on advancing the United States' domestic supply of Critical Materials. To comply with the Strategic and Critical Materials Stock Piling Act, every other year, the U.S. Department of Defense reports on stockpile requirements. In 2013, the U.S. Department of Defense studied 76 materials for the National Defense Stockpile (NDS) Requirements Report. Additionally, the five REEs (Dy, Nd, Tb, Eu and Y) that the U.S. Department of Energy Critical Materials Strategy (2010-2011) deemed to be most critical in the short term for the clean energy economy also appear in the NDS Requirements' Report [17]. For example, magnet and phosphor manufacturers require $\mathrm{Tb}$ and $\mathrm{Eu}$, two of the least abundant REE. These industries will likely be significantly affected in the short term by REE supply issues. Other industries, such as manufacturers of petroleum refining catalysts requiring $\mathrm{La}$ and $\mathrm{Ce}$, will be less impacted since those elements are an order of magnitude more abundant [18].

\subsection{Characteristics, Occurrence, Abundance, and Processing}

There are several features in the chemistry of REE, namely lanthanides, which distinguish them from $d$-block metals. Generally, the reactivity of the elements is greater than that of transition metals. A few key features of lanthanides (Ln) are summarized by Cotton [19]:

- Wide range of coordination numbers (generally 6-12, but two, three or four are known).

- Coordination geometries are determined by ligand steric factors rather than crystal field effects.

- They form labile 'ionic' complexes that undergo facile exchange of ligand. 
- The $4 f$ orbits of $\mathrm{Ln}^{3+}$ ions do not participate directly in bonding. Their spectroscopic and magnetic properties are thus largely uninfluenced by the ligand.

- Small crystal field splitting and sharp electronic spectra in comparison with $d$-block metals.

- They prefer anionic ligands with donor atoms of high electronegativity (e.g., O, F).

- They readily form hydrated complexes.

- Insoluble hydroxides precipitate at neutral $\mathrm{pH}$ unless complexing agents are present.

- The chemistry is largely that of one (3+) oxidation state.

- They do not form multiple bonds (e.g., $\mathrm{Ln}=\mathrm{O}$ or $\mathrm{Ln} \equiv \mathrm{N}$ ) of the type known for many transition metals and certain actinides.

- Unlike transition metals, they do not form stable carbonyls and have virtually no chemistry in the 0 oxidation state.

\subsubsection{Occurrences}

In the United States, the major geologic rare earth oxide (REO) occurrences are generally in carbonates and alkaline intrusions, in veins associated with alkaline intrusions, in some iron deposits associated with magmatic-hydrothermal processes, as well as in stream and beach deposits (placers) derived from the erosion of alkaline igneous terranes [20]. Over 100 different REE- bearing minerals are known from REO deposits, 35 of which are outlined in Table 1. The U.S. and world resources are contained primarily in bastnäsite $(\mathrm{Ce}, \mathrm{La})\left(\mathrm{CO}_{3}\right) \mathrm{F}$ and monazite $(\mathrm{Ce}, \mathrm{La}, \mathrm{Nd}, \mathrm{Th})\left(\mathrm{PO}_{4}\right)$. Bastnäsite deposits in China and the United States constitute the largest percentage of the world's rare-earth economic resources, and monazite deposits constitute the second largest segment [21]. A recent work by Weng et al. [22] gives a detailed assessment of REE resources and deposits.

Table 1. A list of some rare earth oxide (REO) minerals. Table modified from Weng et al. [23].

\begin{tabular}{|c|c|c|}
\hline Mineral & Mineral Chemistry & REO wt \% \\
\hline Aeschynite & $(\mathrm{Ce}, \mathrm{Ca}, \mathrm{Fe}, \mathrm{Th})(\mathrm{Ti}, \mathrm{Nb})_{2}(\mathrm{O}, \mathrm{OH})_{6}$ & 36 \\
\hline Allanite (orthite) & $(\mathrm{Ce}, \mathrm{Ca}, \mathrm{Y})_{2}(\mathrm{Al}, \mathrm{Fe}) 3\left(\mathrm{SiO}_{4}\right)_{3}(\mathrm{OH})$ & $3-51$ \\
\hline Ancylite-(Ce) & $\mathrm{SrCe}\left(\mathrm{CO}_{3}\right)_{2}(\mathrm{OH}) \cdot \mathrm{H}_{2} \mathrm{O}$ & $46-53$ \\
\hline Bastnäsite-(Ce) & $(\mathrm{Ce}, \mathrm{La})\left(\mathrm{CO}_{3}\right) \mathrm{F}$ & $70-74$ \\
\hline Britholite-(Ce) & $(\mathrm{Ce}, \mathrm{Ca})_{5}\left(\mathrm{SiO}_{4}, \mathrm{PO}_{4}\right)_{3}(\mathrm{OH}, \mathrm{F})$ & 56 \\
\hline Brockite & $(\mathrm{Ca}, \mathrm{Th}, \mathrm{Ce})\left(\mathrm{PO}_{4}\right) \cdot \mathrm{H}_{2} \mathrm{O}$ & \\
\hline Calcio-ancylite-(Ce) & $(\mathrm{Ca}, \mathrm{Sr}) \mathrm{Ce}_{3}\left(\mathrm{CO}_{3}\right)_{4}(\mathrm{OH})_{3} \cdot \mathrm{H}_{2} \mathrm{O}$ & 60 \\
\hline Cerianite- $(\mathrm{Ce})$ & $\left(\mathrm{Ce}_{4}^{+}, \mathrm{Th}\right) \mathrm{O}_{2}$ & 81 \\
\hline Cerite- $(\mathrm{Ce})$ & $\mathrm{Ce}_{9}{ }^{3+} \mathrm{Fe}^{3+}\left(\mathrm{SiO}_{4}\right)_{6}\left[\mathrm{SiO}_{3}(\mathrm{OH})\right](\mathrm{OH})_{3}$ & 60 \\
\hline Churchite-(Y) & $\mathrm{YPO}_{4} \cdot 2 \mathrm{H}_{2} \mathrm{O}$ & 44 \\
\hline Euxenite-(Y) & $(\mathrm{Y}, \mathrm{Ca}, \mathrm{Ce}, \mathrm{U}, \mathrm{Th})(\mathrm{Nb}, \mathrm{Ta}, \mathrm{Ti})_{2} \mathrm{O}_{6}$ & $<40$ \\
\hline Fergusonite-(Ce) & $(\mathrm{Ce}, \mathrm{La}, \mathrm{Y}) \mathrm{NbO}_{4}$ & 47 \\
\hline Fergusonite-(Y) & $\mathrm{YNbO}_{4}$ & \\
\hline Florencite-(Ce) & $\mathrm{CeAl}_{3}\left(\mathrm{PO}_{4}\right)_{2}(\mathrm{OH})_{6}$ & 32 \\
\hline Fluocerite & $(\mathrm{Ce}, \mathrm{La}) \mathrm{F}_{3}$ & \\
\hline Fluorapatite-(Ce) & $(\mathrm{Ca}, \mathrm{Ce})_{5}\left(\mathrm{PO}_{4}\right)_{3} \mathrm{~F}$ & $0-21$ \\
\hline Gadolinite & $(\mathrm{Ce}, \mathrm{La}, \mathrm{Nd}, \mathrm{Y})_{2} \mathrm{Fe}^{2+} \mathrm{Be}_{2} \mathrm{Si}_{2} \mathrm{O}_{10}$ & 40 \\
\hline Hingganite-(Y) & $\left(\mathrm{Y}, \mathrm{Yb}, \mathrm{Er}_{2}\right)_{2} \mathrm{Be}_{2} \mathrm{Si}_{2} \mathrm{O}_{8}(\mathrm{OH})_{2}$ & \\
\hline Huanghoite-(Ce) & $\mathrm{BaCe}\left(\mathrm{CO}_{3}\right)_{2} \mathrm{~F}$ & 38 \\
\hline Hydroxylbastnäsite-(Ce) & $(\mathrm{Ce}, \mathrm{La})\left(\mathrm{CO}_{3}\right)(\mathrm{OH}, \mathrm{F})$ & 75 \\
\hline Iimoriite- $(\mathrm{Y})$ & $\mathrm{Y}_{2}\left(\mathrm{SiO}_{4}\right)\left(\mathrm{CO}_{3}\right)$ & \\
\hline Kainosite-(Y) & $\mathrm{Ca}_{2}(\mathrm{Y}, \mathrm{Ce})_{2} \mathrm{Si}_{4} \mathrm{O}_{12}\left(\mathrm{CO}_{3}\right) \cdot \mathrm{H}_{2} \mathrm{O}$ & 38 \\
\hline Loparite-(Ce) & $(\mathrm{Ce}, \mathrm{Na}, \mathrm{Ca})(\mathrm{Ti}, \mathrm{Nb}) \mathrm{O}_{3}$ & $32-34$ \\
\hline Monazite-(Ce) & $(\mathrm{Ce}, \mathrm{La}, \mathrm{Nd}, \mathrm{Th}) \mathrm{PO}_{4}$ & $35-71$ \\
\hline Mosandrite & $(\mathrm{Na}, \mathrm{Ca}, \mathrm{Ce})_{3} \mathrm{Ti}\left(\mathrm{SiO}_{4}\right)_{2} \mathrm{~F}$ & $<65$ \\
\hline Parisite-(Ce) & $\mathrm{Ca}(\mathrm{Ce}, \mathrm{La})_{2}\left(\mathrm{CO}_{3}\right)_{3} \mathrm{~F}_{2}$ & 59 \\
\hline Rhabdophane & $(\mathrm{Ce}, \mathrm{La}) \mathrm{PO}_{4} \cdot \mathrm{H}_{2} \mathrm{O}$ & \\
\hline Samarskite-(Y) & $\left(\mathrm{Y}, \mathrm{Ce}, \mathrm{U}, \mathrm{Fe}^{3+}\right)_{3}(\mathrm{Nb}, \mathrm{Ta}, \mathrm{Ti})_{5} \mathrm{O}_{16}$ & 12 \\
\hline Synchysite-(Ce) & $\mathrm{Ca}(\mathrm{Ce}, \mathrm{La})\left(\mathrm{CO}_{3}\right)_{2} \mathrm{~F}$ & $49-52$ \\
\hline Thalénite-(Y) & $\mathrm{Y}_{3} \mathrm{Si}_{3} \mathrm{O}_{10}(\mathrm{OH})$ & 63 \\
\hline Uraninite & $(\mathrm{U}, \mathrm{Th}, \mathrm{Ce}) \mathrm{O}_{2}$ & \\
\hline Vitusite-(Ce) & $\mathrm{Na}_{3}(\mathrm{Ce}, \mathrm{La}, \mathrm{Nd})\left(\mathrm{PO}_{4}\right)_{2}$ & \\
\hline Xenotime-(Y) & $\mathrm{YPO}_{4}$ & $52-67$ \\
\hline Yttrofluorite & $(\mathrm{Ca}, \mathrm{Y}) \mathrm{F}_{2}$ & \\
\hline Yttrotantalite-(Y) & $\left(\mathrm{Y}, \mathrm{U}, \mathrm{Fe}^{2+}\right)(\mathrm{Ta}, \mathrm{Nb}) \mathrm{O}_{4}$ & $<24$ \\
\hline
\end{tabular}


From a geologic perspective, it is no surprise that geothermal fluids can contain measureable quantities of REEs. Geochemists recognize the utility of REEs as powerful tools for tracing geochemical processes within the earth [3]. Numerous studies over the years have reported on the occurrence of REE species in groundwater flow systems. Recently, the work of Neupane and Wendt [24] give a comprehensive collection of geothermal minerals, which will be discussed in more detail in a section to follow. REE also occur in trace amounts in seawater. Elderfield and Greaves [25] report on the distribution of REE in the oceanic water column. The REEs were reported in trace amounts, on the order of $1 \sim 10 \times 10^{-12} \mathrm{~mol} / \mathrm{kg}$.

\subsubsection{Abundance}

Haque et al. [26] report on the crustal abundance, resource tonnage, and years of reserves' estimates. Crustal abundances for REE are in the range of 0.48-68 ppm, and resource timeframes of 600 to 57,000 years of supply (Table 2). The resources have been calculated using data on the percentage of rare earths found in various ore deposits and the known resources of rare earth containing ores [27]. According to the 2017 U.S. Geological Survey, the world resources of rare earth oxides is reported as $120 \mathrm{Mt}[21]$.

Table 2. Summary of rare earth element (REE) crustal abundance, resource tonnage, and years of reserves estimates. Date sources $[2,26]$.

\begin{tabular}{ccccc}
\hline Element & Crustal Abundance (ppm) & Resource Tons & Production Tons/Annum & Years of Reserves \\
\hline $\mathrm{La}$ & 32 & $22,600,000$ & 12,500 & 1800 \\
$\mathrm{Ce}$ & 68 & $317,000,000$ & 24,000 & 1300 \\
$\mathrm{Pr}$ & 9.5 & $4,800,000$ & 2400 & 2000 \\
$\mathrm{Nd}$ & 38 & $16,700,000$ & 7300 & 2300 \\
$\mathrm{Pm}$ & $\mathrm{NA}$ & $2,900,000$ & $\mathrm{NA}$ & $\mathrm{NA}$ \\
$\mathrm{Sm}$ & 7.9 & 244,333 & 700 & 4100 \\
$\mathrm{Eu}$ & 2.1 & $3,622,143$ & 400 & 610 \\
$\mathrm{Gd}$ & 7.7 & 566,104 & 400 & 9100 \\
$\mathrm{~Tb}$ & 1.1 & $2,980,000$ & 10 & 57,000 \\
$\mathrm{Dy}$ & 6 & $\mathrm{NA}$ & 100 & 29,800 \\
$\mathrm{Ho}$ & 1.4 & $1,850,000$ & 10 & $\mathrm{NA}$ \\
$\mathrm{Er}$ & 3.8 & 334,255 & 500 & 3700 \\
$\mathrm{Tm}$ & 0.48 & $1,900,000$ & 50 & 6700 \\
$\mathrm{Yb}$ & 3.3 & 395,000 & 50 & 38,000 \\
$\mathrm{Lu}$ & 0.4 & $9,000,000$ & $\mathrm{NA}$ & $\mathrm{NA}$ \\
$\mathrm{Y}$ & 30 & $\mathrm{NA}$ & 8900 & 1011 \\
$\mathrm{Sc}$ & 22 & & $\mathrm{NA}$ & $\mathrm{NA}$ \\
\hline
\end{tabular}

The authors note that although this assessment is a simplification, since the life of a particular resources will be influenced by discovery of new deposits, technological efficiency such as use of less specific material per product, extraction efficiency of low grade ore, and finally potentially the stream of recovered metal from recycling [26]. A survey on the recycling of REEs is given by Anderson et al. [28].

\subsubsection{Processing}

Figure 1 shows an abridged diagram of the conventional process route of REE ores to REE metal. The primary steps involved are as follows:

1. Mineral mining and comminution;

2. Physical beneficiation, chemical separation, and concentration from the host material in acidic or alkaline solutions;

3. Separation and purification using solvent extraction or ion exchange, and;

4. Reduction of the individual REOs into pure metals [1].

The first step typically includes crushing the ore and separating the REE-bearing minerals by magnetic, flotation, or gravimetric separation. Since this separation process dramatically increases the 
percentage of REOs, typically from a few weight percent to over $50 \mathrm{wt} \%$ a large amount of waste rock (tailings) is generated and typically must be managed onsite.

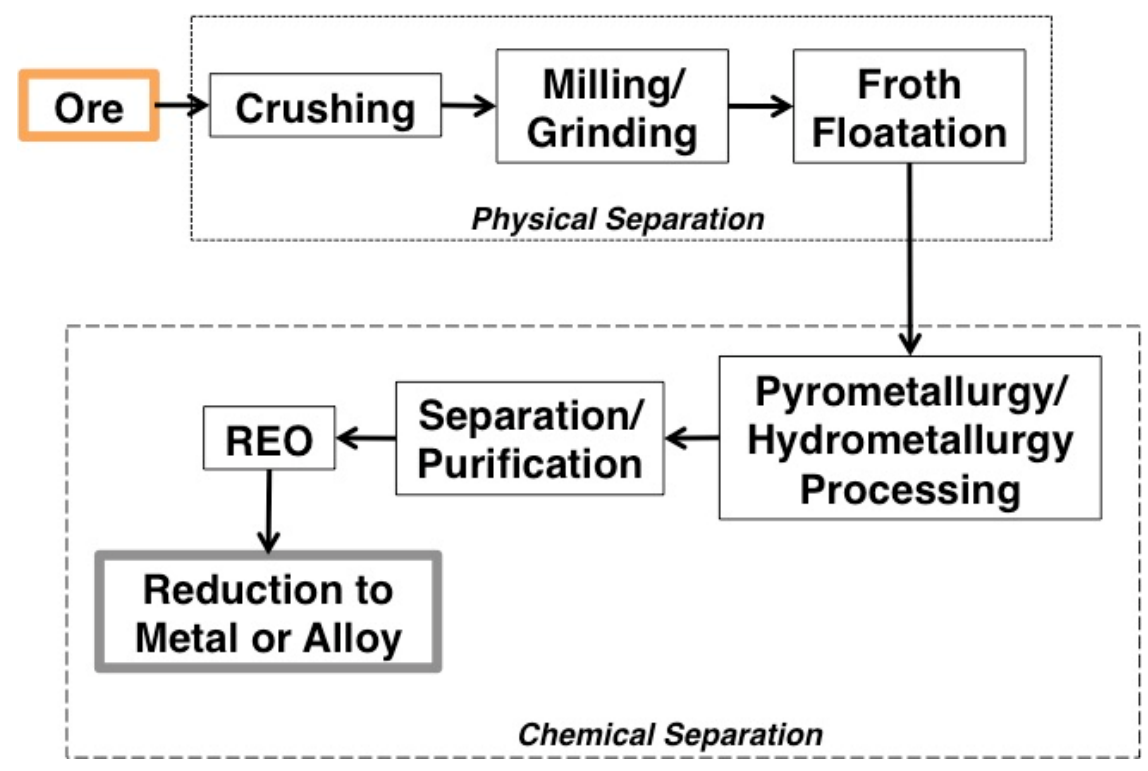

Figure 1. A generalized process flow diagram of rare earth element (REE) processing from ore to final products.

Subsequent steps in the process aim to change the concentrated mineral into more valuable chemical forms with thermal and/or chemical treatments. These typically involve hydrometallurgy (e.g., leaching, extraction, precipitation) or pyrometallurgical techniques (e.g., thermochemical reduction). A fundamental review on REE floatation is given by Anderson et al. [29], while a primer on hydrometallurgical separation of REEs is given by Kronholm et al. [30]. A critical review on solvent extraction of REEs from aqueous solution is given by [31]. Faris et al. reviews the application of ferrous pyrometallurgy for the beneficiation of REE ores [32].

After mineral beneficiation, the most common method of separating REEs is to use ion-exchange resins or solvent extraction methods using tributyl phosphate (TBP) and di-(2-ethylhexyl) phosphoric acid (D2EHPA). Ionic liquids [33,34] have also been investigated for REE separation. After which, the REEs are then often recovered as chlorides, fluorides, or hydroxides. These are then often converted to REOs. The REOs can then be reduced to individual REE metals or an alloy.

It should be noted that the actual REO processing is rather complex and difficulty arises in separation of individual REEs requiring several processing steps. For a more detailed overview of REE extraction and recovery, there are several texts available in the literature (for example, see [35-37]).

\subsection{Environmental Issues in REE Mining and Processing}

The process to recover REEs from geothermal fluids could circumvent some of the significant commercial challenges of conventional rare earth milling and processing. As mentioned, these are complex, ore-specific operations that have the potential for environmental contamination when not controlled and managed appropriately [2]. Weng et al. [23] survey and discuss the environmental impacts of extraction from various types of REE deposits. As noted by Weng et al. [23], there are few published detailed studies on the actual impacts of REE processing. Ali [38] comments on the societal and environmental impacts of the REE industry, suggesting the necessity for a more circular supply chain to lessen such impacts.

Recently, Tharumarajah and Koltun [39] performed Life Cycle Assessment (LCA) on Bayan Obo deposit in China to determine the equivalent greenhouse gas (GHG) emissions for production for 
REOs. Their analysis shows that the production of $\mathrm{Sm}$, Eu and $\mathrm{Gd}$ oxides emits around $55 \mathrm{~kg}$ of $\mathrm{CO}_{2}$ equivalent per $\mathrm{kg}$ of oxide produced. These GHG emission values are significantly higher than for $\mathrm{Fe}$ and $\mathrm{Cu}$, for example. Norgate and Haque [40] determined the global warming potential for Fe to be $11.9 \mathrm{~kg}$ of $\mathrm{CO}_{2}$ equivalent emissions per ton of Fe production, or $\mathrm{kg} \mathrm{CO}_{2}-\mathrm{e} / \mathrm{t}$, bauxite to be $4.9 \mathrm{~kg} \mathrm{CO}$-e/t bauxite, and $\mathrm{Cu}$ concentrate to be $628.2 \mathrm{~kg} \mathrm{CO}_{2}$-e/t Cu concentrate. For $\mathrm{Cu}$ metal, Northey et al. [41] determined $2.6 \mathrm{~kg}$ of $\mathrm{CO}_{2}$ emitted per $\mathrm{kg}$ of produced $\mathrm{Cu}$ metal. A follow-up publication by Koltun and Tharumarajah [42] extended their LCA analysis for REEs produced from the Bayan Obo deposit. In summary, GHG emissions for Light REOs (La-, Ce-, Pr-oxide) to be $32.29 \mathrm{~kg}$ $\mathrm{CO}_{2}$-e/ kg REO, Medium REOs (Nd-, Pm-, Sm-oxide) to be $30.29 \mathrm{~kg} \mathrm{CO}_{2}$-e $/ \mathrm{kg} \mathrm{REO}$, and Heavy REOs (Gd-Lu, Sc-, and Y-oxide) to be $34.49 \mathrm{~kg} \mathrm{CO}$-e/ $\mathrm{kg}$ REO. The oxides, $\mathrm{Eu}_{2} \mathrm{O}_{3}, \mathrm{Dy}_{2} \mathrm{O}_{3}, \mathrm{~Tb}_{4} \mathrm{O}_{7}$ and $\mathrm{Sc}_{2} \mathrm{O}_{3}$ have substantially higher GHG emissions when compared to the other REOs. This is a result of a lower extractable mass when reducing these oxides to metals [42]. For all REE processing, REO separation has the highest contribution to GHG emissions when compared to mining and beneficiation, and reduction.

Radionuclides are often associated with REE mineral deposits including $U$ and Th. Mining and processing of radioactive materials necessitates active and comprehensive monitoring of radiation levels and proper protocols for material handling, processing, and disposal. Table 3 gives a summary of potential environmental impacts in REE mining, processing, and recycling.

Table 3. Summary of potential environmental impacts in REE mining, processing, and recycling. Table adapted from [43].

\begin{tabular}{|c|c|c|}
\hline Activity & Emission Source(s) & Primary Pollutants of Concern \\
\hline \multirow{4}{*}{ Mining } & Overburden & Radiological contaminates \\
\hline & Waste rock & Metals \\
\hline & Sub-ore stockpile & Mine influenced waters (e.g., acid/alkaline drainage) \\
\hline & Ore stockpile & Dust and associated pollutants (e.g., PM 2.5) \\
\hline \multirow{6}{*}{ Processing } & Crushing/Grinding & Dust \\
\hline & Tailings & Radiological contaminates \\
\hline & Tailings impoundment & Metals \\
\hline & Separation and Purification & Turbidity \\
\hline & Liquid waste & Organics \\
\hline & & Dust and associated pollutants \\
\hline \multirow{9}{*}{ Recycling } & Collection & Transportation pollutants \\
\hline & Dismantling and separation & Dust and associated pollutants \\
\hline & Scrap waste & Volatile Organic Compounds \\
\hline & Landfill & Metals \\
\hline & Processing & Dust and associated pollutants \\
\hline & & Volatile Organic Compounds \\
\hline & & Dioxins \\
\hline & & Metals \\
\hline & & Organics \\
\hline
\end{tabular}

\section{REEs in Geothermal Brines}

Neupane and Wendt [24] present a recent and comprehensive study on the mineral contents of geothermal brines in the U.S. Data from 8000 entries was compiled and summarized in their study. In regard to REEs, a separate database was also prepared from journal articles published by Wood et al. [44-48] and ongoing Idaho National Laboratory (INL) projects analyzing geothermal/oil and gas well brines of the eastern Snake River Plain, southeastern Idaho, and Wyoming Basin. Figure 2 shows a representation of the data compiled by Neupane and Wendt [24] of total filtered REE concentration $(\mathrm{ng} / \mathrm{kg}$, or parts per trillion) versus well $\mathrm{pH}$. Not all of the data from Neupane and Wendt's study [24] was extracted.

We can see that the majority of the samples collected contain sub-ppb levels of REEs and the fluids are alkaline in nature. For REEs levels above the ppb range, the fluids typically have an acidic $\mathrm{pH}$. REE adsorption is generally favored at near neutral or slightly basic $\mathrm{pH}$. It should to be noted that 
unfiltered samples often contain much higher concentration of RE than filtered samples. Of the REEs present in geothermal fluids, the most abundant REEs typically are La, Ce and Nd.

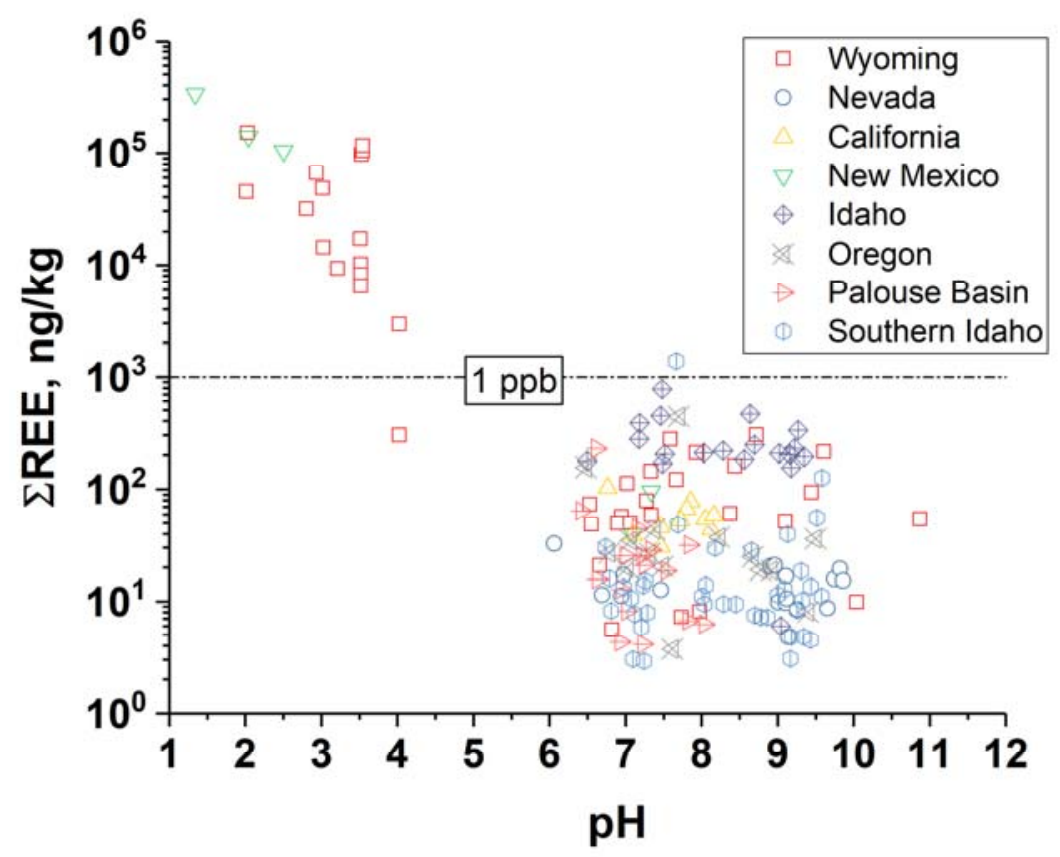

Figure 2. Filtered brine concentration of total REEs in solution plotted versus brine $\mathrm{pH}$. The figure is a representation of the data complied from Neupane and Wendt [24] and not all data was extracted.

\section{Potential Methods of REE Extraction from Geothermal Brines}

Extracting REE at such a low concentration from geothermal brines is challenging. Unknown mineral abundance and cost effective technology for separation from geothermal brine present addition challenges. Recently, significant efforts are being made to develop technologies to extract REE from geothermal brine, since the geothermal brine can be a cost-effective mineral resource [25]. Several technologies have been developed and suggested for the extraction of REEs using geothermal brine as a resource. However, the suggested techniques are still in lab-scale studies, and significant work is required before these are used in real applications. Some of the suggested techniques that can be used to recover REEs from the geothermal brine are discussed.

All of the methods discussed here are fundamentally separation processes. Metrics for the effectiveness of the separation is often measured by the selectivity, energy and water use, and waste production. For viable separation, the total operating cost cannot be greater than the value of recovered REEs. Environmental costs should be accounted for ideally; however, many are hard to quantify monetarily.

\subsection{Adsorption}

Adsorption can be used to recover metal ions from low-concentration sources by means of relatively simple processes. Recovering REEs using adsorbents involves a combination of solid-phase sorbents, water treatment, and established mineral processing unit operations. This approach offers advantages such as environmental friendliness, scalability, and high processing speed. Research to date showed that the new sorbent materials can be integrated into relevant mineral recovery structures such as packed beds, fluidized beds, various filter structures, and various thin membranes. A variety of sorbents show high affinities towards a variety of REEs with good capacities, rapid kinetics, and economics. Although many REE adsorbents have been studied [49-61], to date, there is no adsorbent material in practical use. 
Metal oxide adsorbents such as the oxides of Fe and Mn [62] have been predominantly examined for REE adsorption. Functionalized magnetic nanoparticles, for example [63], have gained considerable interest due to simple recovery of the adsorbent material via magnetic field. In particular, a project at Pacific Northwest National Laboratory (PNNL, Richland, WA) [64,65] examined composite nanoparticles having a core structure of magnetic iron oxide and an active shell structure made of silica or metal organic framework (MOF) sorbent functionalized using chelating ligands selective to REEs. Their process introduces these nanoparticles at a low concentration (about $0.05 \mathrm{wt} \%$ ) into the concentrated geothermal fluid (using plant heat exchanger). The process is designed for a short interaction of concentrated brine with the functionalized nanoparticles to bind REEs on surface of the particles. Separating out the nanoparticles with an electromagnet followed by standard extraction techniques extracts the REEs. The study at PNNL identified the two MOF (i)-SO3-(ii) diethylene triamine (DETA) that can be used to selectively adsorb REE. These MOFs were shown to effectively stripped five REEs in simulated brine solution when the nanoparticles were exposed for $5 \mathrm{~min}$. A 20\% rate of return was showed in the experimental study for REE extraction at PNNL. Functionalized carbons have also been examined for REE extraction. Recently, we have demonstrated the application of recycled tires as an adsorbent for the extraction of aqueous REEs such as Y, La, Ce, Sm and Nd [66].

\subsection{Ion-Exchange}

Ion exchange (IX) is a highly effective separation technique mainly for dilute solutions. Development of synthetic resins in the 1940s marked a significant advance in development of commercial IX processes. Separation of REE into their individual components as part of the Manhattan Project in World War II was a notable achievement of IX [67]. Subsequent development of chelating resins was a significant advancement in applications of IX to metallurgical separations [68]. The use of IX resins and chelation IX resins is common in commercial systems to selectively separate metal ions. Some advantages of IX process includes a simple design, applicable to dilute feeds, has the ability to achieve a high concentration factor, and has virtually no loss of separation media to the environment. The downside to IX is that the method does not work well with concentrated feeds, the kinetics are usually slow, and depending on the separation agent used selectivity can be limited. For IX, selectivity is based on the metal ion charge, while for chelation IX, high selectivity is achieved with ligands [68]. Selective adsorbents may improve the economics of extraction over IX resins. Generally adsorbents can tolerate a wider domain of operating conditions, whereas IX requires more pretreatment.

\subsection{Solvent Extraction (SX)}

Solvent extraction involves transfer of a solute from one liquid phase to another immiscible or partially immiscible liquid that is in contact with the first phase [68]. The first phase (aqueous) contains the metal to be concentrated into the second phase. The second phase consists of an organic liquid containing an active extractant and appropriate modifiers dissolved in a solvent (diluent). The leach solution and the organic liquid form immiscible phases and must have low mutual solubilities. Upon contact, the dissolved metal or metal complex ions and the extractant molecules undergo chemical exchange reactions [69]. The metal ions are then recovered through a stripping process of the organic phase. In the metal industry, SX is extensively used in recovery of $\mathrm{Cu}$ from ore leach solutions, amounting to approximately a quarter of global $\mathrm{Cu}$ production [67]. Limitations of SX arise from the use of organic volatile, combustible, and toxic solvents. Often, traces of solvent components are carried into effluent streams, which necessitate environmental abatement. A review on SX for REEs is given by Xie at al. [31].

\subsection{MRT-Molecular Recognition Technology}

This process, termed molecular recognition technology (MRT), is effective at various stages in metal life cycles $[70,71]$. The MRT process is based on selective recognition of specific metal ion guests 
by supported ligand hosts allowing highly selective individual separation and recovery of metals from complex matrices present in industrial feed solutions.

An early application of molecular recognition to selective host-guest interactions was the pioneering work of Pedersen, for which he shared the Nobel Prize in 1987 [72]. Pedersen synthesized a large number of cyclic polyethers [73] and observed that certain number of these had remarkable selectivity for specific alkali metal ions. This selective host-guest interaction was quantitated and its range expanded to other macrocycles by Izatt et al. [74,75] and others [76]. Early work by Izatt and coworkers with selective transport of metal ions in supported liquid membrane systems [77] led to the development of solid supported SuperLig ${ }^{\circledR}$ systems (IBC Advanced Technologies, American Fork, UT, USA) in which the metal-selective ligand was attached by a tether to a solid support, such as silica gel [78]. This achievement made large scale, selective metal separations possible [79]. After passing several volumes of brine, the species of interest can be stripped and concentrated using aqueous ethylenediaminetetraacetic acid/ $\mathrm{HCl}$ solution. The MRT procedure is described [79] and examples are given of its commercial use, environmental, procedural, economic, metal conservation, and metal resource preservation benefits associated with the use of green chemistry principles are discussed.

\subsection{Extraction Using Engineered Microbes}

Metals leaching using microbes is an established technique for metals extraction from liquid media [80]. The approach is based on the fact that some microorganisms such as bacteria bind with metal ions. An early study made an assessment for metal binding capacities of bacteria based on a dry weight basis, and estimated that binding capacity of bacteria is quite comparable to the binding capacities of commercial ion exchangers $\left(10^{-5}\right.$ to $10^{-3} \mathrm{~mol}$ metal/g) [81]. In various studies, several mesophilic bacteria have been engineered to show the metal-binding motifs on their cell surface with increased binding capacity and selectivity [82-86]. For example, binding of $\mathrm{Gd}^{3+}$ with the bacteria has been demonstrated [87]. Following that, a selective bioleaching technique is recently proposed to recover REE metals from geothermal fluid based on the lab scale experiment [88]. In the study, Geobacillus stearothermophilus was used as a biosorbent and SbsB protein as a surface layer (S-layer) scaffold to recover the Gd in geothermal fluid. In the approach, the S-layer modification by mesophile Escherichia coli was suggested. With the engineered S-layer, the binding efficiency of $\mathrm{Gd}^{3+}$ ions was increased up to $80 \%$ in $\mathrm{nM}$ concentration of $\mathrm{Gd}$ in geothermal brine. A review on the biosorption and bioaccumulation of valuable metals from geothermal brine is presented by Lo et al. [89]. These data demonstrate that the bioleaching can be a possible technique to recover REEs from the geothermal fluid present in trace levels; however, to establish this as a viable technique, a significant amount of research is required. Although such an approach may have a low capital cost, the kinetics may be lagging.

\subsection{Magnetic Segregation}

O'Brian [90] describes in a patent a magnetic segregation method that can be used to recover REEs from the geothermal fluids. The method involves collection of the hot geothermal brine in a heat exchanger followed by cooling the hot fluid down. As the fluid cools down, REEs in the brine condense out of the fluid, forming a condensate. The condensate is then accelerated by applying a physical force (gravity or centrifuge), followed by applying a magnetic force simultaneously. Due to combinations of both physical and magnetic forces, the components of condensate segregate differently. The segregated REEs can be collected and removed from the condensate. The process can be optimized by varying the duration, intensity, time and constancy of the two forces to for the segregation of the REEs from other components of the condensates.

\section{Discussion}

The possibility of extracting minerals from the geothermal brines has been a great interest to the geothermal communities including private sector and various government agencies [91-94]. 
Numerous studies, ranging from the brine characterization to operation at pilot level to extract minerals from the geothermal brines have been reported [94-96]. Over the years, several technologies to extract minerals such as precious minerals ( $\mathrm{Ag}, \mathrm{Au}, \mathrm{Pd}, \mathrm{Pt}, \mathrm{Cs}$ and $\mathrm{Sr}$ ), $\mathrm{Cu}, \mathrm{Sn}, \mathrm{Li}, \mathrm{Mg}$, from geothermal brine are developed. The precious metals (PMs) extraction from the geothermal brine has gained considerable interest. PMs are present in the geothermal brines in the $0.1-10$ ppb range, whereas the concentrations of PMs in scale are found to be higher, in the 100-1000 s of ppb range. Since the price of the PMs is orders of magnitude greater than that of REEs (i.e., 10,000 \$/kg for PMs vs. 1-100 \$/kg for REOs), economic benefits have long been identified. The well-established extraction technologies to extract some of the PMs from geothermal brine and scale are summarized in Table 4.

Table 4. Extraction technologies for precious metals (PMs) from geothermal brines.

\begin{tabular}{ccc}
\hline Minerals & Extraction Technology & Reference \\
\hline \multirow{3}{*}{$\mathrm{Ag}$} & Sulphidization & {$[97]$} \\
& Precipitation by metallic iron & {$[93]$} \\
& Deposition in steel vessel & {$[98]$} \\
\hline \multirow{3}{*}{$\mathrm{Au}$} & Scale deposition & {$[99]$} \\
& Deposition in extraction vessel & {$[98]$} \\
$\mathrm{Pt}$ & Bioleaching & {$[100]$} \\
$\mathrm{Sr}$ & Carbon interaction with brine & {$[100]$} \\
& Evaporative extraction & {$[101]$} \\
\hline
\end{tabular}

The extraction of PMs from geothermal brine has been demonstrated to have economical benefit using essentially the same technologies/methods as that would be used for REE extraction. However, extraction of REEs is not viable due to economic constrains and a much higher volume of demand. To compare, the U.S. consumption of all REE metals and compounds was estimated to be $17,000 \mathrm{t}$ of REO in 2014 [102]. In the same year for Au, the U.S. produced around $200 \mathrm{t}$ and consumption was reported to be $150 \mathrm{t}$ [103]. If we average all of the data points (total of 160 data points) in Figure 2, for a rough estimation of total REEs in the resources, the REE concentration is around $0.17 \mathrm{ppm}$. In contrast, REO ore grades in conventional mining are typically $0.05-0.5 \%$ or $500-5000 \mathrm{ppm}$.

Due to the low concentration and low price, economic extraction of REE from geothermal brine alone does not appear to be viable. If we assume a typical geothermal power plant operates at a flow rate of $20 \mathrm{~kg} / \mathrm{s}$ of brine for $1 \mathrm{MW}_{\mathrm{e}}$ power $\left(200{ }^{\circ} \mathrm{C}\right.$ reservoir) [104], a typical $20 \mathrm{MW}$ facility passes around $1.26 \times 10^{10} \mathrm{~kg}$ /year of brine through its facility. If we assume the brine to have a REE content of approximately $100 \mathrm{ppb}$ REEs, this comes to around $1261 \mathrm{~kg}$ of extractable REEs. Now, if we assume the distribution of REEs in the brine to have a similar REE distribution as that of Mountain Pass ore (49.6\% Ce, 32.4\% La, $12.37 \% \mathrm{Nd}$, assume balance with gangue) and a $90 \%$ recovery, $358 \mathrm{~kg} \mathrm{of} \mathrm{La}_{2} \mathrm{O}_{3}$, $563 \mathrm{~kg}$ of $\mathrm{CeO}_{2}$, and $140 \mathrm{~kg}$ of $\mathrm{Nd}_{2} \mathrm{O}_{3}$ for a total of around $1071 \mathrm{~kg}$ REEs recovered per year could be expected. If we assume market prices (buying) of 2, 2 and $42 \$ / \mathrm{kg}$ for $\mathrm{CeO}_{2}, \mathrm{La}_{2} \mathrm{O}_{3}$ and $\mathrm{Nd}_{2} \mathrm{O}_{3}$, respectively, only around $\$ 7700$ worth of REEs can be viably collected. Note that this does not take into account processing costs of the REEs. This one processing plant would contribute to approximately $0.006 \%$ of REE domestic demand.

Geothermal energy production cost is around $0.04-0.10 \$ / \mathrm{kWh}$, with capital cost estimates of around $2500 \$ / \mathrm{kW}$ installed. If we again assume the base case of a $20 \mathrm{MW}$ facility, the capital cost of the power plant is approximately $\$ 50,000,000$ with an annual operating cost of $\$ 7,000,000$ at $0.04 \$ / \mathrm{kWh}$. If REE extraction will help reduce operating costs by an additional revenue stream, the selling of REOs would contribute to $0.11 \%$ or less of the operating budget. To be noted, the revenue calculated for REOs does not account for any processing costs of the REOs. Given this crude analysis with several assumptions, REE extraction from geothermal brine only seems feasible if extracted with other co-products. Neupane and Wendt [24] concluded in their study that certain value can be extracted 
from geothermal brines, namely from silica and lithium. Given today's market value and technology, silica and lithium are currently the only economical extractable minerals.

\section{Conclusions}

This work has made an attempt to briefly summarize studies on REEs in geothermal fluids and technologies for the extraction thereof. Recovering REEs from geothermal fluids presents many advantages, but these are not met with out technical challenges and economical constraints. The following conclusions can be drawn from this study:

- REEs are present in measureable quantities in geothermal fluids using modern analytical techniques

- A number of technologies exist for extraction of REEs from geothermal fluids

- Due to the low concentration of REEs in the fluid, REEs recovered from geothermal fluids does not present itself as a resource able to meet current domestic demand

- Economic constraints hinders the viability for REE extraction alone

- Co-recovery with other valuable metals and minerals will improve the overall economic feasibility.

Acknowledgments: This work was supported in part by the Dawn and Roger Crus Renewable Energy Center, College of Mines and Earth Sciences, University of Utah, Salt Lake City, UT, USA. The authors would like to thank Pamela Bogust for assistance in preparing this work.

Author Contributions: Y.R.S. developed the concept. P.K. and Y.R.S. wrote on technologies for extraction, and J.D.M wrote on mineral resources and geothermal energy. Y.R.S. and J.D.M discussed and analyzed the data. Y.R.S. wrote the remaining sections of the manuscript. All authors reviewed a final version.

Conflicts of Interest: The authors declare no conflict of interest.

\section{References}

1. Gupta, C.; Krishnamurthy, N. Extractive metallurgy of rare earths. Int. Mater. Rev. 1992, 37, 197-248. [CrossRef]

2. Reisman, D.J.; Weber, R.J. Rare Earth Elements: A Review of Production, Processing, Recycling, and Associated Environmental Issues; U.S. Environmental Protection Agency: Cincinnati, OH, USA, 2012.

3. Johannesson, K.H. Rare Earth Elements in Groundwater Flow Systems; Springer Science \& Business Media: Dordrecht, The Netherlands, 2006.

4. DiPippo, R. Geothermal Power Generation: Developments and Innovation; Woodhead Publishing: Cambridge, UK, 2016.

5. Moore, J.N.; Simmons, S.F. More power from below. Science 2013, 340, 933-934. [CrossRef] [PubMed]

6. Lewis, A.J.; Komninou, A.; Yardly, B.W.D.; Palmer, M.R. Rare earth element speciation in geothermal fluids from Yellowstone National Park, Wyoming, USA. Geochim. Cosmochim. Acta 1988, 62, 657-663. [CrossRef]

7. Fowler, A.P.; Zierenberg, R.A. Rare earth element concentrations in geothermal fluids and epidote from the Reykjanes geothermal system, Iceland. In Proceedings of the World Geothermal Congress 2015, Melbourne, Australia, 19-25 April 2015.

8. Bakane, P. Overview of extraction of minerals/metals with the help of geothermal fluid. In Proceedings of the 38th Workshop on Geothermal Reservoir Engineering Stanford University, Stanford, CA, USA, 11-13 February 2013.

9. Segneri, B.; Deprizio, J.; Reinhardt, T. Geologic provenance of rare earth elements in the united states, and their potential collocation with geothermal resources. In Proceedings of the Thirty-Ninth Workshop on Geothermal Reservoir Engineering Stanford University, Stanford, CA, USA, 24-26 February 2014.

10. Gallup, D.L. Geochemistry of geothermal fluids and well scales, and potential for mineral recovery. Ore Geol. Rev. 1998, 12, 225-236. [CrossRef]

11. Jacoby, M.; Jiang, J. Securing the supply of rare earths. Chem. Eng. News 2010, 88, 9-12. [CrossRef]

12. Gschneidner, K.A., Jr. The rare earth crisis-The supply/demand situation for 2010-2015. Mater. Matters 2011, 6, 32-37.

13. Voncken, J.H.L. The Rare Earth Elements: An Introduction; Springer: Berlin/Heidelberg, Germany, 2015.

14. USGS. National Minerals Information Center. Available online: http://minerals.usgs.gov/minerals/ (accessed on 5 October 2014). 
15. Bauer, D.; Diamond, D.; Li, J.; Sandalow, D.; Telleen, P.; Wanner, B. 2010 Critical Materials Strategy; U.S. Department of Energy: Washington, DC, USA, 2010.

16. Grasso, V.B. Rare Earth Elements in National Defense: Background, Oversight Issues, and Options for Congress; U.S. Environmental Protection Agency: Cincinnati, OH, USA, 2013.

17. Office of the Under Secretary of Defense for Acquisition, Technology and Logistics. Strategic and Critical Materials 2013 Report on Stockpile Requirements; U.S. Department of Defense: Arlington, VA, USA, 2013.

18. Jordens, A.; Cheng, Y.P.; Waters, K.E. A review of the beneficiation of rare earth element bearing minerals. Miner. Eng. 2013, 41, 97-114. [CrossRef]

19. Cotton, S. Lanthanide and Actinide Chemistry; John Wiley \& Sons: Hoboken, NJ, USA, 2013.

20. Long, K.R.; Van Gosen, B.S.; Foley, N.K.; Cordier, D. The Principal Rare Earth Elements Deposits of the United States: A Summary of Domestic Deposits and A Global Perspective; Springer: Berlin/Heidelberg, Germany, 2012.

21. Ober, J.A. Mineral Commodity Summaries 2017; U.S. Geological Survey: Reston, VA, USA, 2017.

22. Weng, Z.; Jowitt, S.M.; Mudd, G.M.; Haque, N. A detailed assessment of global rare earth element resources: Opportunities and challenges. Econ. Geol. 2015, 110, 1925-1952. [CrossRef]

23. Weng, Z.; Jowitt, S.; Mudd, G.; Haque, N. Assessing rare earth element mineral deposit types and links to environmental impacts. Appl. Earth Sci. 2013, 122, 83-96. [CrossRef]

24. Neupane, G.; Wendt, D.S. Assessment of mineral resources in geothermal brines in the us. In Proceedings of the 42nd Workshop on Geothermal Reservoir Engineering, Stanford University, Stanford, CA, USA, 13-15 February 2017.

25. Elderfield, H.; Greaves, M.J. The rare earth elements in seawater. Nature 1982, 296, 214-219. [CrossRef]

26. Haque, N.; Hughes, A.; Lim, S.; Vernon, C. Rare earth elements: Overview of mining, mineralogy, uses, sustainability and environmental impact. Resources 2014, 3, 614-635. [CrossRef]

27. Humphries, M. Rare earth elements: The global supply chain. Congr. Res. Serv. 2012, 2011, 7-5700.

28. Anderson, C.; Anderson, C.; Taylor, P. Survey of recycled rare earths metallurgical processing. Can. Metall. Q. 2013, 52, 249-256. [CrossRef]

29. Anderson, C.D.; Taylor, P.R.; Anderson, C.G. Rare Earth Floatation Fundamentals: A Review. In Proceedings of the XXVIII International Mineral Processing Congress 2016, Quebec City, QC, Canada, 11-15 September 2016.

30. Kronholm, B.; Anderson, C.G.; Taylor, P.R. A primer on hydrometallurgical rare earth separations. JOM 2013, 65, 1321-1326. [CrossRef]

31. Xie, F.; Zhang, T.A.; Dreisinger, D.; Doyle, F. A critical review on solvent extraction of rare earths from aqueous solutions. Miner. Eng. 2014, 56, 10-28. [CrossRef]

32. Faris, N.; Ram, R.; Tardio, J.; Bhargava, S.; McMaster, S.; Pownceby, M.I. Application of ferrous pyrometallurgy to the beneficiation of rare earth bearing iron ores-A review. Miner. Eng. 2017, 110, 20-30. [CrossRef]

33. Guo, L.; Chen, J.; Shen, L.; Zhang, J.; Zhang, D.; Deng, Y. Highly selective extraction and separation of rare earths(III) using bifunctional ionic liquid extractant. ACS Sustain. Chem. Eng. 2014, 2, 1968-1975. [CrossRef]

34. Sun, X.; Waters, K.E. Development of industrial extractants into functional ionic liquids for environmentally friendly rare earth separation. ACS Sustain. Chem. Eng. 2014, 2, 1910-1917. [CrossRef]

35. Krishnamurthy, N.; Gupta, C.K. Extractive Metallurgy of Rare Earths; CRC Press: Boca Raton, FL, USA, 2004.

36. Eyring, L. Progress in the Science and Technology of the Rare Earths; Elsevier: Amsterdam, The Netherlands, 2013.

37. Lucas, J.; Lucas, P.; Le Mercier, T.; Rollat, A.; Davenport, W.G. Rare Earths: Science, Technology, Production and Use; Elsevier: Amsterdam, The Netherlands, 2014.

38. Ali, S. Social and environmental impact of the rare earth industries. Resources 2014, 3, 123-134. [CrossRef]

39. Tharumarajah, R.; Koltun, P. Cradle to gate assessment of environmental impact of rare earth metals. In Proceedings of the 7th Australian Conference on Life Cycle Assessment, Melbourne, Australia, 9-10 March 2011.

40. Norgate, T.; Haque, N. Energy and greenhouse gas impacts of mining and mineral processing operations. J. Clean. Prod. 2010, 18, 266-274. [CrossRef]

41. Northey, S.; Haque, N.; Mudd, G. Using sustainability reporting to assess the environmental footprint of copper mining. J. Clean. Prod. 2013, 40, 118-128. [CrossRef]

42. Koltun, P.; Tharumarajah, A. Life cycle impact of rare earth elements. ISRN Metall. 2014, 2014. [CrossRef]

43. Gammons, C.H.; Wood, S.A.; Jonas, J.P.; Madison, J.P. Geochemistry of the rare-earth elements and uranium in the acidic Berkeley Pit lake, Butte, Montana. Chem. Geol. 2003, 198, 269-288. [CrossRef] 
44. Van Middlesworth, P.E.; Wood, S.A. The aqueous geochemistry of the rare earth elements and yttrium. Part 7. REE, Th and U contents in thermal springs associated with the idaho batholith. Appl. Geochem. 1998, 13, 861-884. [CrossRef]

45. Nelson, B.J.; Wood, S.A.; Osiensky, J.L. Rare earth element geochemistry of groundwater in the Palouse Basin, northern Idaho-eastern Washington. Geochem. Explor. Environ. Anal. 2004, 4, 227-241. [CrossRef]

46. Wood, S.A. The aqueous geochemistry of the rare-earth elements and yttrium: 1 . Review of available low-temperature data for inorganic complexes and the inorganic ree speciation of natural waters. Chem. Geol. 1990, 82, 159-186. [CrossRef]

47. Wood, S.A.; Shannon, W.M. Rare-earth elements in geothermal waters from Oregon, Nevada, and California. J. Solid State Chem. 2003, 171, 246-253. [CrossRef]

48. Araki, K.; Yoshida, M.; Uezu, K.; Goto, M.; Furusaki, S. Lanthanide-imprinted resins prepared by surface template polymerization. J. Chem. Eng. Jpn. 2000, 33, 665-668. [CrossRef]

49. Alakhras, F.A.; Dari, K.A.; Mubarak, M.S. Synthesis and chelating properties of some poly(amidoximehydroxamic acid) resins toward some trivalent lanthanide metal ions. J. Appl. Polym. Sci. 2005, 97, 691-696. [CrossRef]

50. Bou-Maroun, E.; Goetz-Grandmont, G.J.; Boos, A. Sorption of europium(III) and copper(II) by a mesostructured silica doped with acyl-hydroxypyrazole derivatives-Extraction, kinetic and capacity studies. Colloids Surf. A 2006, 287, 1-9. [CrossRef]

51. Chen, Y.G.; Zhu, B.H.; Wu, D.B.; Wang, Q.G.; Yang, Y.H.; Ye, W.M.; Guo, J.F. Eu(III) adsorption using di(2-ethylhexyl) phosphoric acid-immobilized magnetic GMZ bentonite. Chem. Eng. J. 2012, 181, 387-396. [CrossRef]

52. Choi, S.H.; Lee, K.P.; Sohn, S.H. Graft copolymer-lanthanide complexes obtained by radiation grafting on polyethylene film. J. Appl. Polym. Sci. 2003, 87, 328-336. [CrossRef]

53. Das, N.; Das, D. Recovery of rare earth metals through biosorption: An overview. J. Rare Earths 2013, 31, 933-943. [CrossRef]

54. Dupont, D.; Brullot, W.; Bloemen, M.; Verbiest, T.; Binnemans, K. Selective uptake of rare earths from aqueous solutions by edta-functionalized magnetic and nonmagnetic nanoparticles. ACS Appl. Mater. Interfaces 2014, 6, 4980-4988. [CrossRef] [PubMed]

55. Jia, Q.; Wang, Z.H.; Li, D.Q.; Niu, C.J. Adsorption of heavy rare earth(III) with extraction resin containing bis(2,4,4-trimethylpentyl) monothiophosphinic acid. J. Alloys Compd. 2004, 374, 434-437. [CrossRef]

56. Ramakrishnan, K.; Rao, T.P. Ion imprinted polymer solid phase extraction (IIP-SPE) for preconcentrative separation of erbium(III) from adjacent lanthanides and yttrium. Sep. Sci. Technol. 2006, 41, 233-246. [CrossRef]

57. Shibata, J.; Matsumoto, S.; Yamamoto, H. A novel separation technology for a heavy rare earth residue using a solvent impregnated resin. Solvent Extr. Res. Dev. Jpn. 2000, 7, 167-175.

58. Wang, F.; Zhao, J.; Zhou, H.; Li, W.; Sui, N.; Liu, H. O-carboxymethyl chitosan entrapped by silica: Preparation and adsorption behaviour toward neodymium (III) ions. J. Chem. Technol. Biotechnol. 2013, 88, 317-325. [CrossRef]

59. Wu, D.; Sun, Y.; Wang, Q. Adsorption of lanthanum (III) from aqueous solution using 2-ethylhexyl phosphonic acid mono-2-ethylhexyl ester-grafted magnetic silica nanocomposites. J. Hazard. Mater. 2013, 260, 409-419. [CrossRef] [PubMed]

60. Ogata, T.; Narita, H.; Tanaka, M. Adsorption behavior of rare earth elements on silica gel modified with diglycol amic acid. Hydrometallurgy 2015, 152, 178-182. [CrossRef]

61. Koeppenkastrop, D.; De Carlo, E.H. Uptake of rare earth elements from solution by metal oxides. Environ. Sci. Technol. 1993, 27, 1796-1802. [CrossRef]

62. Ashour, R.M.; El-sayed, R.; Abdel-Magied, A.F.; Abdel-khalek, A.A.; Ali, M.; Forsberg, K.; Uheida, A.; Muhammed, M.; Dutta, J. Selective separation of rare earth ions from aqueous solution using functionalized magnetite nanoparticles: Kinetic and thermodynamic studies. Chem. Eng. J. 2017, 327, 286-296. [CrossRef]

63. Thomas, H.; Reinhardt, T.P.; Segneri, B. Low temperature geothermal mineral recovery program. In Proceedings of the 40th Workshop on Geothermal Reservoir Engineering, Stanford University, Stanford, CA, USA, 26-28 January 2015.

64. Thomas, H.P.; Reinhardt, T.P.; Andersen, A.; Segneri, B. Critical and strategic materials and potential importance for geothermal projects. In Proceedings of the 41st Workshop on Geothermal Reservoir Engineering, Stanford University, Stanford, CA, USA, 22-24 February 2016. 
65. Smith, Y.R.; Bhattacharyya, D.; Willhard, T.; Misra, M. Adsorption of aqueous rare earth elements using carbon black derived from recycled tires. Chem. Eng. J. 2016, 296, 102-111. [CrossRef]

66. Izatt, R.M.; Izatt, S.R.; Bruening, R.L.; Izatt, N.E.; Moyer, B.A. Challenges to achievement of metal sustainability in our high-tech society. Chem. Soc. Rev. 2014, 43, 2451-2475. [CrossRef] [PubMed]

67. Rao, S.R. Resource Recovery and Recycling from Metallurgical Wastes; Elsevier: Amsterdam, The Netherlands, 2011; Volume 7.

68. Sohn, H.Y. Hydrometallurgical principles. In Reference Module in Materials Science and Materials Engineering; Elsevier: Amsterdam, The Netherlands, 2016.

69. Izatt, N.E.; Bruening, R.L.; Krakowiak, K.E.; Izatt, S.R. Contributions of professor Reed M. Izatt to molecular recognition technology: From laboratory to commercial application. Ind. Eng. Chem. Res. 2000, 39, 3405-3411. [CrossRef]

70. Izatt, S.R.; Bruening, R.L.; Izatt, N.E. Metal separations and recovery in the mining industry. JOM 2012, 64, 1279-1284. [CrossRef]

71. Izatt, R.M. Charles J. Pedersen: Innovator in macrocyclic chemistry and co-recipient of the 1987 Nobel Prize in chemistry. Chem. Soc. Rev. 2007, 36, 143-147. [CrossRef] [PubMed]

72. Pedersen, C.J. Cyclic polyethers and their complexes with metal salts. J. Am. Chem. Soc. 1967, 89, 7017-7036. [CrossRef]

73. Izatt, R.M.; Nelson, D.; Rytting, J.; Haymore, B.; Christensen, J.J. Calorimetric study of the interaction in aqueous solution of several uni-and bivalent metal ions with the cyclic polyether dicyclohexyl-18-crown-6 at 10,25, and 40.deg. J. Am. Chem. Soc. 1971, 93, 1619-1623. [CrossRef]

74. Lamb, J.; Izatt, R.; Swain, C.; Christensen, J. A systematic study of the effect of macrocycle ring size and donor atom type on the $\log \mathrm{K}$,.DELTA.H, and T.DELTA.S of reactions at 25.degree.C in methanol of mono-and divalent cations with crown ethers. J. Am. Chem. Soc. 1980, 102, 475-479. [CrossRef]

75. Christensen, J.J.; Eatough, D.J.; Izatt, R.M. The synthesis and ion bindings of synthetic multidentate macrocyclic compounds. Chem. Rev. 1974, 74, 351-384. [CrossRef] [PubMed]

76. Izatt, R.; Lamb, J.; Bruening, R. Comparison of bulk, emulsion, thin sheet supported, and hollo fiber supported liquid membranes in macrocycle-mediated cation separations. Sep. Sci. Technol. 1988, 23, 1645-1658. [CrossRef]

77. Izatt, R.M.; Bruening, R.L.; Bruening, M.L.; Tarbet, B.J.; Krakowiak, K.E.; Bradshaw, J.S.; Christensen, J.J. Removal and separation of metal ions from aqueous solutions using a silica-gel-bonded macrocycle system. Anal. Chem. 1988, 60, 1825-1826. [CrossRef]

78. Izatt, R.M.; Izatt, S.R.; Izatt, N.E.; Krakowiak, K.E.; Bruening, R.L.; Navarro, L. Industrial applications of molecular recognition technology to separations of platinum group metals and selective removal of metal impurities from process streams. Green Chem. 2015, 17, 2236-2245. [CrossRef]

79. Gadd, G.M. Biosorption: Critical review of scientific rationale, environmental importance and significance for pollution treatment. J. Chem. Technol. Biotechnol. 2009, 84, 13-28. [CrossRef]

80. Vijayaraghavan, K.; Yun, Y.-S. Bacterial biosorbents and biosorption. Biotechnol. Adv. 2008, 26, $266-291$. [CrossRef] [PubMed]

81. Valls, M.; Atrian, S.; de Lorenzo, V.; Fernández, L.A. Engineering a mouse metallothionein on the cell surface of Ralstonia eutropha CH34 for immobilization of heavy metals in soil. Nat. Biotechnol. 2000, 18, 661-665. [CrossRef] [PubMed]

82. Kuroda, K.; Ueda, M. Bioadsorption of cadmium ion by cell surface-engineered yeasts displaying metallothionein and hexa-His. Appl. Microbiol. Biotechnol. 2003, 63, 182-186. [CrossRef] [PubMed]

83. Nishitani, T.; Shimada, M.; Kuroda, K.; Ueda, M. Molecular design of yeast cell surface for adsorption and recovery of molybdenum, one of rare metals. Appl. Microbiol. Biotechnol. 2010, 86, 641-648. [CrossRef] [PubMed]

84. Pazirandeh, M.; Chrisey, L.; Mauro, J.; Campbell, J.; Gaber, B. Expression of the neurospora crassa metallothionein gene in escherichia coli and its effect on heavy-metal uptake. Appl. Microbiol. Biotechnol. 1995, 43, 1112-1117. [CrossRef] [PubMed]

85. Park, D.M.; Reed, D.W.; Yung, M.C.; Eslamimanesh, A.; Lencka, M.M.; Anderko, A.; Fujita, Y.; Riman, R.E.; Navrotsky, A.; Jiao, Y. Bioadsorption of rare earth elements through cell surface display of lanthanide binding tags. Environ. Sci. Technol. 2016, 50, 2735-2742. [CrossRef] [PubMed]

86. Daughtry, K.D.; Martin, L.J.; Sarraju, A.; Imperiali, B.; Allen, K.N. Tailoring encodable lanthanide-binding tags as MRI contrast agents. Chem. Biol. Chem. 2012, 13, 2567-2574. [CrossRef] [PubMed] 
87. Charrier, M.; Ajo-Franklin, C.M. Engineering thermophilic microorganisms to selectively extract strategic minerals. In Proceedings of the 42nd Workshop on Geothermal Reservoir Engineering, Stanford University, Stanford, CA, USA, 13-15 February 2017.

88. Lo, Y.C.; Cheng, C.L.; Han, Y.L.; Chen, B.Y.; Chang, J.S. Recovery of high-value metals from geothermal sites by biosorption and bioaccumulation. Bioresour. Technol. 2014, 160, 182-190. [CrossRef] [PubMed]

89. O’brien, T.B. Recovery of Elements from Hydrothermal Products. U.S. Patent 8377165, 19 February 2013.

90. Werner, H. Contribution to the mineral extraction from supersaturated geothermal brines salton sea area, California. Geothermics 1970, 2, 1651-1655. [CrossRef]

91. Kennedy, A. The recovery of lithium and other minerals from geothermal water at Wairakei. In Proceedings of the UN Conference on New Sources of Energy, Rome, Italy, 21-31 August 1961.

92. Maimoni, A. Minerals recovery from salton sea geothermal brines-A literature review and proposed cementation process. Geothermics 1982, 11, 239-258. [CrossRef]

93. Harrison, S. Technologies for Extracting Valuable Metals and Compounds from Geothermal Fluids; California Energy Commission: Sacramento, CA, USA, 2014.

94. Wood, S.A. Behavior of Rare Earth Element in Geothermal Systems; A New Exploration/Exploitation Tool; University of Idaho (US): Moscow, ID, USA, 2002.

95. Bourcier, W.; Bruton, C.; Roberts, S.; Viani, B.; Conley, S.; Martin, S. Pilot-Scale Geothermal Silica Recovery at Mammoth Lakes; California Energy Commission: Sacramento, CA, USA, 2009.

96. Farley, E.; Watson, E.; MacDonald, D.; Bartlett, R.; Krishnan, G. Recovery of Heavy Metals from High Salinity Geothermal Brine; SRI International: Menlo Park, CA, USA, 1980.

97. Brown, K.L.; Roberts, P.J.C. Extraction of gold and silver from geothermal fluid. In Proceedings of the 10th New Zealand Geothermal Workshop, Auckland, New Zealand, 2-4 November 1988.

98. Brown, K.L. Gold deposition from geothermal discharges in New Zealand. Econ. Geol. 1986, 81, 979-983. [CrossRef]

99. Premuzic, E.T.; Lin, M.S.; Bohenek, M.; Bajsarowicz, V.; McCloud, M. Advanced Biochemical Processes for Geothermal Brines: Current Developments; Brookhaven National Lab.: Upton, NY, USA, 1997.

100. Gallup, D.L.; Ririe, G.T. Platinum Recovery. U.S. Patent 5290339, 1 March 1994.

101. Christopher, D.; Stewart, M.; Rice, J. The Recovery and Separation of Mineral Values from Geothermal Brines. Research Report, 1974-1975; Hazen Research, Inc.: Golden, CO, USA, 1975.

102. Gambogi, J. Rare earths. In 2014 Minerals Yearbook; U.S. Gological Survey: Reston, VA, USA, 2016.

103. Gambogi, J. Gold. In 2014 Minerals Yearbook; U.S. Gological Survey: Reston, VA, USA, 2016.

104. Moore, J. Personal communication, Energy \& Geoscience Institute: Salt Lake City, UT, USA, 2017. 